\title{
Strategic Analysis of English Teaching Reform in Universities and Colleges under the Background of the "Belt and Road" Strategy
}

\author{
Shaojie $\mathbf{W u}^{*}$ \\ Enshi Polytechnic, Enshi, Hubei, 445000, China
}

\begin{abstract}
In recent years, the "Belt and Road" as a newly proposed economic strategy has not only created a new type of economic development model, but also brought some reforms to the current English education in Universities and Colleges. Based on the analysis of the relationship between the "Belt and Road" and the English teaching in universities and colleges, the author makes suggestions for the innovation of teaching ideas, aiming to cultivate more outstanding talents for the strategic development of the "Belt and Road".

Keywords: The "Belt and Road"; University and college English; Teaching reform; Teaching model

*Corresponding Author: Shaojie Wu, Enshi Polytechnic, No. 122 Xueyuan Road, Enshi, Hubei, 445000, China; E-mail: 978756790@qq.com.
\end{abstract}

DOI: $10.36012 /$ fhe.v 1 i1 1.570

\section{Introduction}

$\mathrm{U}$ nder the influence of the "Belt and Road" strategic environment, the university and college education system has also been optimized and improved, and at the same time, it has put forward higher requirements for English teaching in universities and colleges. In the context of the development of "Belt and Road", the reform of English teaching in universities and colleges has become an urgent task for the development of universities and colleges. In order to better realize the goal of college English teaching, we must always take the development of students as the core, focus on cultivating students' cultural literacy and communication skills, stimulate students' development awareness, and improve students' professional ability, so as to meet the current needs of social development, and promote the sustainable development of English teaching in universities and colleges.

\section{The "Belt and Road" Development Strat- egy}

In 2013, President Xi Jinping proposed the "Belt and Road" construction strategic goal, which promoted the development of economic globalization and created a cooperation model for the international regional economy, which highlights the economic, political and cultural development mission of coastal countries under the opening up and development situation. From the perspective of the historical development process, the Silk Road has a long history. The "Belt and Road" strategy has promoted cooperation in Central Asia, effectively exerting the cultural advantages of the provinces and cities, and promoting the integration of national economic development through cultural exchanges. As the main language of communication in the world, English has the important task of cultural communication and communication. This requires that higher vocational English can base on market demand, 
transform teaching mode, and cultivate more specialized compound talents for social development. ${ }^{[1]}$

\section{The Objective Requirements of the "Belt and Road" Strategy for English Teaching in Universities and Colleges}

\subsection{The Requirements for University and College} Students' English Listening and Speaking Skills

Under the environmental background of the "Belt and Road", the process of cultural exchange and trade cooperation between countries along the route requires that our current university and college students must have professional listening and speaking skills. In English teaching, universities and colleges should further clarify the students' learning status, effectively combine students' listening and speaking in English learning, and increase the guidance and exchange of students in the classroom, encourage students to enhance oral practice with flexible methods and improve their English listening and speaking skills, thus promoting the transformation of English teaching in universities and colleges under the environment of the "Belt and Road" development strategy.

3.2 The Cultivation of University and College Students' Cross-cultural Consciousness

In the process of cultivating university and college students' ability, universities and colleges should base themselves on the development strategy of the "Belt and Road" and do a good job in cultural communication and promotion, which requires strengthening the knowing and understanding of the culture of countries along the route to better achieve the effectiveness of cultural exchanges and cooperation. Based on the foundation of English teaching in universities and colleges, it is necessary to intensify the awareness of intercultural communication among college students, guide students to respect other countries' cultures with an open and inclusive perspective, broaden students' horizons, and enhance students' comprehensive qualities to adapt to the English teaching requirements under the "Belt and Road" strategic environment.

3.3 The Requirements for University and College Students' Professional English Abilities

Under the development strategy of the "Belt and Road”, university and college students must have professional English skills. As an important basis for international exchanges and cooperation, English must have certain normative and professionalism in the development of the "Belt and Road" strategy, which requires the English ability of university and college students to meet the professional development requirements of various fields. ${ }^{[2]}$ Under such teaching objectives, English teachers in universities and colleges should further adjust the goals of English teaching, clarify the orientation of teaching, increase cultural exchanges, and strengthen the connection between English majors and practical applications, so as to better improve the comprehensive professional quality and quality of university and college students.

\section{The Current Problems of English Teach- ing in Universities and Colleges}

\subsection{Lack of Reasonable English Teaching Concepts}

Influenced by the traditional test-oriented education in the past, English teaching in universities and colleges in China still continues the shadow of exam-oriented education, which leads students to have strong ability in English professional knowledge examination. However, once some practical problems are encountered, there is a lack of resilience. Some of the practical abilities in English vocabulary, speaking and listening are difficult to adapt to the current social development needs. In addition, because students have been in an indoctrinated teaching mode for a long time, they have lost their main status in English learning, and they have been learning according to the teaching and methods of teachers, which leads to the inability to get divergent, and has a certain negative impact on the enthusiasm as well as the learning efficiency of university and college students.

\subsection{Insufficient Innovation in English Teaching}

The economic development of the society is inseparable from the education of colleges and universities. Especially with the rapid and efficient development of the society, it is easy to see the bad phenomenon of paying attention to economic development and neglecting education. At present, China has increased its investment higher education, however, the innovation of educational theory still remains to be perfect. The English teaching in some universities and colleges still stays in the traditional education mode in the past, and it is difficult to achieve good educational results. ${ }^{[3]} \mathrm{In}$ order to make university and college English education better suited to economic development, it is necessary to innovate the education model in the development 
background of the "Belt and Road" to strengthen the cultivation of university and college students' English listening and speaking abilities, therefore, it is possible to train more high-quality talents with strong communicative competence for the "Belt and Road".

\subsection{Unbalanced Cultural Proportions of Chinese} and Western Countries in Textbooks

"The Teaching Requirements of University and College English Courses" clearly stipulate that the comprehensive application ability of students should be taken as the main goal of teaching. The purpose is to enable some non-English majors to effectively carry out cross-cultural communication in work and social communication. Generally speaking, intercultural communication refers not only to Western culture in English textbooks, but also to the introduction of Chinese culture in English. In the current "New Horizon College English" (Third Edition), each volume contains 8 units of contents, such as the fourth volume, which involves little Chinese culture. However, in this textbook, the practice part of Chinese-English translation is obviously biased towards the contents of Chinese traditional culture, including four famous works and ancient inventions. Even so, as a whole, Chinese culture clearly accounts for a small proportion of the content of Chinese and Western cultures.

\subsection{English Teachers Lack the Accumulation and Training of Chinese Culture}

Many English teachers focus on the teaching of language in the teaching process, and do not effectively connect and combine Western culture and Chinese culture. The listening materials and video materials used by the teachers in the students' listening training are also from some British and American film and television dramas, so that students can feel the original English pronunciation. But in this way, the infiltration of Chinese culture was greatly ignored. In addition, in recent years, there has been more and more research on the integration of ideological and political education in university and college English teaching, and some English teachers can also feel the lack of their own Chinese cultural knowledge. Therefore, university and college English teachers must not only enhance their professional English ability, but also actively participate in some knowledge training on Chinese culture to further enhance the cultivation of Chinese culture.

\section{The Reform of University and College English Education under the Background of the "Belt and Road"}

\subsection{Plan Professional Courses to Improve Universi- ty and College Students' Comprehensive English Professional Literacy}

In the teaching of English teaching in universities and colleges, it is necessary to rationally plan professional courses and appropriately increase the proportion of Chinese culture, which requires relevant personnel to revise the current university and college English textbooks. In the curriculum revision process of university and college English teaching, we must also consider the vocabulary that should be mastered at different stages, and clarify the sentences and phrases related to Chinese culture. University and college English textbooks can not only be limited to foreign literature and newspapers, but to adapt to the current "Belt and Road" strategic background and increase the elements of Chinese culture, and actively open some English elective courses that can be combined with Chinese culture, so that students can learn more about Chinese culture in the process of learning English.

\subsection{Reform Teaching Methods and Infiltrate Chi- nese Cultural Elements}

At any time, university and college English teachers should recognize the important role of traditional culture in university and college English teaching. In the process of university and college English teaching, teachers must change the teaching methods of the past and incorporate some knowledge related to Chinese cultural elements into the English teaching curriculum. For example, in the learning process of different units, Based on the content and knowledge points of the textbooks, teachers could guide students to combine the content of the textbooks to compare the differences between Chinese and Western cultures, conduct group discussions or exchanges, collect some information related to the problem, improve the interest of Chinese and Western cultural studies, and enhance the team's ability to collaborate. In the English class, teachers can also incorporate some interpretations and translations of Chinese traditional culture, such as the Spring Festival, Lantern Festival, Double Ninth Festival and other traditional festivals, or allow students to translate some Chinese proverbs and Western proverbs, in this way, not only the students' English application ability is 
improved, but also their cultivation in Chinese culture is improved. At present, many English teachers are systematically pursuing English majors from the undergraduate stage, lacking systematic research on Chinese culture. However, in the strategic environment of the "Belt and Road", university and college English teachers should strengthen their emphasis on Chinese culture, enrich their cultural resources through micro-course, MOOC, and continue education, actively participate in the training and learning of Chinese culture, and improve their traditional culture. ${ }^{[4]}$

\subsection{Renew Trad itional Education Concepts and Strengthen Oral and Listening Exercises}

Compared with the English education in the middle school stage, the English education in universities and colleges is more diversified, but there is indeed a certain gap in the effectiveness of teaching. The reason is mainly because the purpose of university and college students' learning English is no longer the consolidation of basic knowledge and the practice of listening and speaking will be reduced compared with the high school period. Most of the teaching aims to develop students' ability to pass the English proficiency test, which leads to the purpose of students' English learning is to cope with the exam. Under normal circumstances, teachers use specialized textbooks for teaching. In the process of guiding students' knowledge learning, they also use adequate English teaching plans and textbooks. On the whole, the focus of current university and college English teaching is still centered on reading and writing, while listening and speaking are incidental. In addition, the setting of English teaching time in universities and colleges is limited. Therefore, English teachers in universities and colleges should effectively combine listening and oral teaching, save the time of class, and innovate teaching methods. For example, in the teaching method, students should be guided to read the text in advance, correct the pronunciation of the students on the basis of familiarity, or combine some scenes to simulate the content of the textbooks, so that the students' learning and practice can be effectively combined, therefore, some phrases and vocabulary can be flexibly used, which not only helps students master the basic knowledge, but also enhances their self-confidence in learning and better realizes the application of English teaching in universities and colleges.

Under the strategic background of the "Belt and
Road", university and college English teachers need to update their teaching concepts, and on the basis of strengthening students' comprehensive English development ability, to meet the needs of cross-cultural communication. Therefore, university and college English teaching should strengthen oral and listening training, lay a good foundation for cultivating comprehensive talents, and make useful contributions to the current global economic development.

\subsection{Cultivate Cross-Cultural Consciousness and Pro- mote China's Economic and Cultural Development}

The economic development strategy of the "Belt and Road" involves many countries, from the western border of China, there are eight countries bordering Xinjiang, mainly Mongolia, the Russian Federation, the Republic of Kazakhstan, the Kyrgyz Republic, etc., so the culture involved is very different. Therefore, in order to better adapt to international exchanges, China needs to focus on cultivating students' cross-cultural awareness in university and college English education. Specifically, we need to understand the different cultural backgrounds and humanities differences in each country in English learning. Teachers should also let students understand the importance of cultural differences to language in their thinking. Specifically, we need to understand the different cultural backgrounds and humanities differences in each country in English learning. Teachers should also let students understand the importance of cultural differences to language in their thinking. It can be said that different countries have different cultural backgrounds and different language expressions. The degree of language understanding will affect the effect of international communication to a certain extent. In the aspect of education, teachers need to provide students with cultural backgrounds and ethnic backgrounds for each country, broaden the field of knowledge in the classroom, not only limited to textbooks, but also to expand in history, religion, etc., so that students can fully understand the differences in cultures of different countries, respect and learn the differences of culture, in the future work of international exchanges, we can understand foreign cultures and promote Chinese culture to better understand China and promote China's economic and cultural development.

5.5 Strengthen Job Application Practice and Carry out School-Enterprise Cooperative Teaching

English teaching in universities and colleges can not 
only rely on the training and education of the classroom, but also can effectively connect with the enterprise, provide students with practical value positions, and enable students to strengthen their English ability through practice, thus improving the effectiveness of English teaching. Through practical application, students can also have a most intuitive understanding of their abilities, so that they can clearly learn and check for vacancies in future students. In addition, university and college English teachers should also be aware that English translation and application are closely related. If effective translation is not possible, it will be difficult to contribute to economic development and communication under the development background of "Belt and Road". Therefore, in the school-enterprise cooperation, it is necessary to strengthen the application and exercise of translation posts. In the process of school-enterprise cooperation, students' safety and learning effects are also some factors that should be considered. In order to better realize the effect of English teaching in universities and colleges, schools and enterprises should adopt a developmental perspective to provide some support for the current university and college English teaching reform.

It can be said that regarding the purpose of English teaching in universities and colleges, we can not only be limited to the examination objectives of the fourth and sixth grades (CET-4, CET-6), but also strengthen the students' comprehensive ability in language learning. The ability of students to learn, listen, speak, read and write in the process of learning English is inseparable from the penetration and accumulation of culture. Under the current development of the "Belt and Road" strategy, university and college students shoulder an important mission and need to spread Chinese culture to the world. It may be necessary to effectively absorb the advanced experience and culture of other countries. Therefore, in addition to improving the English level of university and college students, university and college English teachers should also inculcate the knowledge of Chinese and Western cultures, effectively integrate Chinese culture into the process of English teaching, and explore the teaching reform model that adapts to the development strategy of the "Belt and Road".

\section{Conclusion}

In general, the development goal of the "Belt and Road" is to promote China's economic and cultural development in the exchange of the world economy. The economic benefits of "Belt and Road" are not only reflected in international trade and economic development, but also have a positive effect on the development of various fields in China. University and College English education is an important way for China to communicate and cooperate with the countries along the "Belt and Road", which needs our attention. In order to make our country more powerful in the development of the global economy, we need to increase the reform of English teaching in universities and colleges, and establish a long-term development goal, which is closely integrated with the current development strategy of the "Belt and Road", will make a positive contribution to the country's training of outstanding and comprehensive development talents.

\section{References}

[1] Yi Peng, Huijun Zhao. Research on the Cultural Communication Function of English Teaching in Universities and Colleges under the "Belt and Road" Initiative[J]. Forum on Contemporary Education, 2017(3):83-91. (in Chinese)

[2] Bin Xu. Research on University and College English Translation Teaching under the Background of "Belt and Road" —Based on Bourdieu Cultural Capital Theory[J]. Education Forum, 2017(33):157-159. (in Chinese)

[3] Na Lv. The Strategy of Innovative Ability Cultivation in University and College English Classroom Teaching under the Background of "Belt and Road" [J]. Theoretical Observation, 2017(4):162-164. (in Chinese)

[4] Xia Huang. The Reform of Public English Teaching in Universities and Colleges under the Perspective of "Belt and Road”[J]. Journal of Chizhou University, 2017(5):152-154. (in Chinese) 